al. The efficacy of infection surveillance and control programs in preventing nosocomial infections in US hospitals. $A m J$ Epidemiol 1985;121:183-205.

3. Brown RB, Hosmer D, Chen HC, Teres D, Sands M, Bradley S, et al. A comparison of infections in different ICUs within the same hospital. Crit Care Med 1985; 13:472-476.

4. Milliken J, Tait GA, Ford-Jones EL, Mindorff CM, Gold R, Mullins G. Nosocomial infections in a pediatric intensive care unit. Crit Care Med 1988;16:233-237.

5. Skippen P, Cox P, Langley JM, et al. Nosocomial infections in the PICU: epidemiology and control. In: Fuhrman BP, Zimmerman JJ, eds. Pediatric Critical Care. St Louis, MO: Mosby; 1992:965-988.

6. Singh-Naz N, Sprangue BM, Patel KM, Pollack MM. Risk factors for nosocomial infection in critically ill children: a prospective cohort study. Crit Care Med 1996;24:875-878.

7. Nosocomial infection rates for interhospital comparison: limitations and possible solutions. A report from the National Nosocomial Infections Surveillance (NNIS) System. Infect Control Hosp Epidemiol 1991;12:609-621.

8. Garner JS, Jarvis WR, Emori TG, Horan TC, Hughes JM. CDC definitions for nosocomial infections, 1988. Am J Infect Control 1988;16:128-140.

9. Donowitz LG. High risk of nosocomial infection in the pediatric critical care patient. Crit Care Med 1986;14:26-29.

10. Jarvis WR, Edwards JR, Culver DH, Hughes JM, Horan T, Emori TG, et al. Nosocomial infection rates in adult and pediatric intensive care units in the United States. National Nosocomial Infections Surveillance System. Am J Med 1991;91 (suppl 3B):185S-191S.

\title{
Endoscopic Disinfection and Reprocessing of Endoscopic Accessories: A Must Read
}

\section{Gina Pugliese, RN, MS Martin S. Favero, PhD}

Dr. Charles Lightdale, Professor of Clinical Medicine, Columbia University, and Dr. Richard A. Kozarek, Chief of Gastroenterology, Virginia Mason Medical Center, Seattle, Washington, are, respectively, consulting and guest editors for the April 2000 issue of Gastrointestinal Endoscopy Clinics of North America. This issue, in the form of a hard-covered book, contains the most up-to-date collection of papers that describe the successes and failures associated with the art and science of reprocessing endoscopes.
Among the 16 chapters are the following: (1) Overview of Infection Control Problems: Principles in Gastrointestinal Endoscopy, by Walter W. Bond; (2) Infectious Complications Associated With Gastrointestinal Endoscopy, Drew B. Schembre; (3) The Microbial Flora of the Gastrointestinal Tract and the Cleaning of Flexible Endoscopes, Nancy S. Chu and Martin Favero; (4) Automatic Flexible Endoscope Reprocessors, Lawrence F. Muscarella; (5) FDA Guidelines for Endoscope Reprocessing, Mary J. Cornelius; (6) American Society for Gastrointestinal Endoscopy-Society of Gastroenter- ology Nurses and Associates Endoscope Reprocessing Guidelines, Virginia Walter and Anthony DiMarino, Jr; (7) Reconciliation of FDA and Societal Guidelines for Endoscope Reprocessing, Carla Alvarado; and (8) Methodology of Reprocessing Reusable Accessories, Michelle Alfa.

FROM: Gastrointestinal Endoscopy Clinics of North America. Kozarek RA, Lightdale CJ, eds. Endoscopic Disinfection and Reprocessing of Endoscopic Accessories. Philadelphia, PA: WB Saunders Co; 2000;10(2). 